\title{
Empowerment of Women as a Form of Soft Power to Prevent the Terrorism Action
}

\author{
Seniwati $^{1 \mathrm{a}}$; Dwia Aries Tina Pulubuhu ${ }^{2}$; Andi Alimuddin ${ }^{3}$ \\ ${ }^{1}$ International Relations Department, Hasanuddin University, Makassar, Indonesia \\ ${ }^{2}$ Sociology Department, Hasanuddin University, Makassar, Indonesia \\ ${ }^{3}$ Communication Department, Hasanuddin University, Makassar Indonesia \\ ${ }^{\mathrm{a}}$ Corresponding author: seniwatiunhas2016@gmail.com
}

\begin{abstract}
This paper focuses on the empowerment of women in preventing the terrorism action. The empowerment of women is one of the forms of soft power. In preventing the occurrence of terrorism, which required not only hard power but also soft power. The activity is one form of the empowerment of women in preventing the occurrence of terrorism. This paper aims to determine the economic activities undertaken by women as a form of soft power and as one way in preventing the occurrence of terrorism. This research is case study. Case study is one type of qualitative research. This research was conducted in Pinrang District. This study found that women have a big role in the field of entrepreneurship. Women in this area develop a cake or traditional food. Pinrang Regency has traditional food that needs to be kept preserved. This traditional food has its own meaning when presented. The government should support the entrepreneurship of women in Pinrang Regency. This effort will raise the family economy that will ultimately create family welfare. A prosperous family will not think to participate in terrorist activities.
\end{abstract}

Keywords-entrepreneuship, preventing the terrorism action, soft power, women

\section{INTRODUCTION}

Women have a big role in preventing the occurrence of terrorism. Therefore, the government needs to involve women in various sectors as a form in preventing the occurrence of terrorism. Moreover, it is also necessary to transform. Dominic in her article states "based on definition, a society is transforming constantly from one condition to another condition in as showed through shifts in their elements such as in ideological, artistic, social, and cultural" [2]. This statement provides an overview that transformation has occurred in the community in various sectors such as social, cultural, ideological, and artistic sectors. Transformation is a change experienced by society. Transformation is required for a better goal.

Transformation can also support the empowerment of women. Empowerment of women is one form of soft power. At first, women can only be active at home. They should not have other activities outside the home because of tradition. Jones states the condition in Indonesia De Jure, almost always males are head a household, even the husband is decrepit and old... [8]. Currently, women have activities outside the home.
Slowly women begin to respond to social issues of society and disseminate the issue to families and also to other friends. Women provide news about the dangers of terrorism. They also ask the family not to fall into the temptations of terrorism.

Women have the power to fight terrorism therefore women can become bastions in maintaining peace in the world. To counter terrorism, women must have education and strength. Foreign Minister Retno says women around the world are preparing education and strength because women are one of the nation's foundations. If women have education and strength, women can work together. This will make women an agent of strength [10]. Women in the Pinrang area also have many activities such as building partnerships to improve the economic life of their families. The economic condition of the family to be good will form harmony in the family. This condition will cause the family not to think in support of terrorist activities. This paper aims to determine the economic activities undertaken by women as a form of soft power and as one way in preventing the occurrence of terrorism.

\section{RESEARCH METHOD}

The method is qualitative. The approach used is case study. Case study is one type of qualitative methodology [9]. The case study method focuses on an intensive and detailed case. Place of research conducted in Indonesia, South Sulawesi Province, Pinrang District, Subdistrict Paleteang Benteng Sawitto. The study period from May to August 2017. Research target is women who active in entrepreneurship sector. The liveliness of women in the entrepreneurship sector is one form of the empowerment of women. The empowerment of women movement is a form of soft power. Soft power is one way in preventing the occurrence of terrorism. Through case study research, we can know the role of women in preventing the occurrence of terrorism.

\section{RESULT AND DISCUSSION}

Women can act as a peace-building by preventing family members from participating in terrorist activities. Gender equality and empowerment are promoted by UN Women in 2010. A woman has the crucial role as a preventer especially in their family. Women could be as a partner to prevent someone to engage groups or ideologies of extremist. Fink et.al. state 
women can join as preventer and participator in shaping, informing and implementing programs and policies in mitigating the effects of violent radicalization and conflict [3].

The efforts undertaken by the Pinrang Regency community in preventing their family to join terrorism movement in their area is giving contribution to the entrepreneurship sector. Society of Pinrang promotes their natural product. Women develop the economic empowerment to establish the gender equality. One of the economic sectors developed by women in Pinrang Regency is participating in entrepreneurial activities. Empowering women in entrepreneurship requires special education to develop Small and Medium Enterprises.

Pinrang community entrepreneurship activities are ranging from organizing, manufacturing, and managing traditional food businesses. Society organizes the business that they will do in terms of raw materials. People also make their own entrepreneurial materials. Then, they manage their entrepreneurship. Activities undertaken include selling "bebek nasu palekko" (name of traditional food of Pinrang District). Bebek nasu palekko is one of the traditional food in Pinrang Regency. One way of managing this traditional food business is through social media such as email, forums and blogs. Haryani and Motwani in their article state information faster than ever before could be distributed by online communities, social networks, forum, online videos, email and blogs [4]. Managing traditional businesses using the Internet and social media makes it more successful than ever.

FIGURE 1. TRADITIONAL FOOD OF PINRANG REGENCY

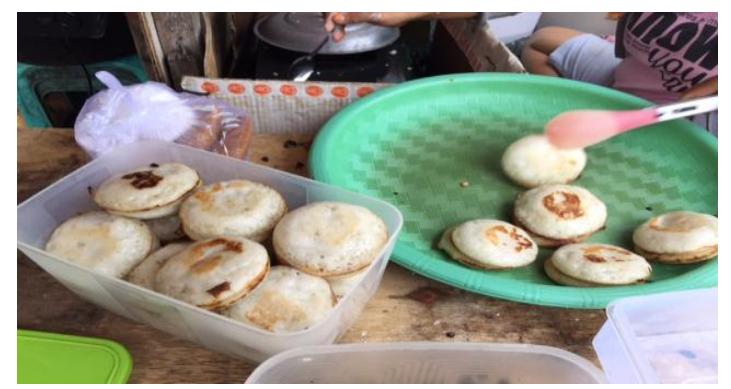

The picture above is one example of Pinrang Regency community effort in developing characteristic of traditional regional cake. Development of culinary business is one manifestation of the role of women in preventing family members to participate in terrorism activities. This is a traditional cake business opportunity that can support women's business in the region. To that end, the government needs to improve the competitiveness of traditional products by maximizing traditional products.

This food production business has a noble mission of supporting national food security. This effort will help the government in improving people's welfare. Therefore, the government must fully support the process of developing traditional businesses. In the midst of the development of the era of modernization, the traditional cake-selling price should be increased. To support this condition, product quality standards are required. Some efforts made for traditional cake products can be maintained quality, including 1) Materials used from the best material; 2) Selected local product has great potential to be marketed; 3) The processing is done in accordance with the standard of quality experience; 4) Have a good marketing and business management strategy.

The importance of maintaining the quality of traditional food products because these traditional foods not only convey the cake maker's expression but also maintain the relationship between society and the environment and the religion it embraces. Therefore food is one of the most important components in society [5]. Some traditional cakes should be displayed during custom occasions or religious events. As in the picture below:

FIGURE 2. PEOPLE CONSUME THE TRADITIONAL CAKE AT THE RELIGIOUS CEREMONY IN EXPRESSING THE RELATIONSHIP BETWEEN SOCIETIES

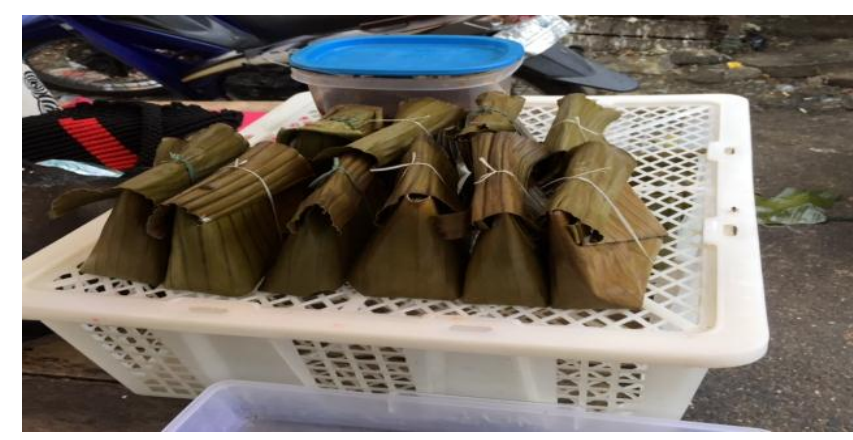

People usually consume the above cake traditional in religious ceremony. The cake is for ethnic group especially Bugis and Makassar ethnics. This means that traditional foods can express the relationship between one person and another. The above traditional cakes are usually also consumed at the time of the wedding party. Ma further explains in her writings that food can give an expression of the relationship of interpersonal [5]. In Bugis culture, some traditional cakes or foods can show the closeness of the person who consumed the cakes.

FIGURE 3. PEOPLE IN PINRANG REGENCY CONSUME THE TRADITIONAL CAKE TO EXPRESS THE RELATIONSHIP CLOSENESS TO THE GUEST

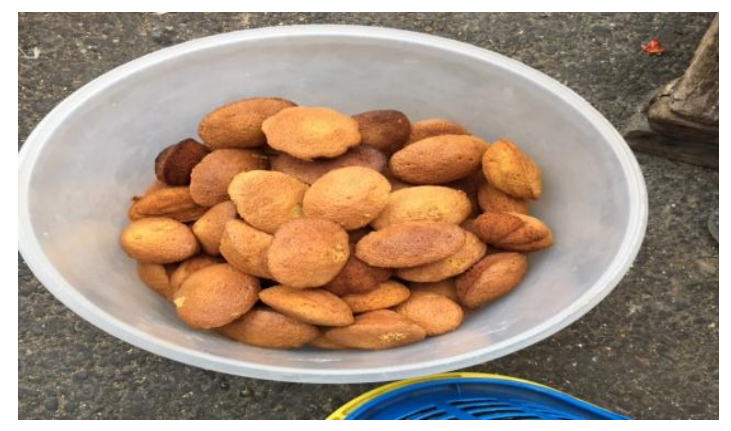

The cake in the picture above is usually presented to friends close to the owner of the house. In her article, Ma says food can show one's social status [5]. Social status shows a social layer based on economic criteria. Social status can also mean the position or position of a person in a community 
group. People who have high economic conditions can only display some traditional foods.

The above description shows the importance of traditional food position. To maintain the existence of traditional food, the empowerment of women is needed. Local government programs should include women empowerment. Empowerment of women is one form of soft power in the fight against terrorism. Nye in his work has distinguished between soft power and hard power [6]. Moreover, Nye in his book explains that culture, institutions and ideology as intangible power associate with emulation and attraction are persuasive power [7]. Intangible power is one of crucial element in soft power.

Then, the role of institutions especially local governments in supporting empowerment is needed as one of the strategies in countering terrorism. Cooper in his article states "in domestic and international level, soft power has the important role" [1]. This condition provides an overview, soft power is used not only at the international level but also at the national level. Empowerment provides an opportunity to build gender equality.

\section{CONCLUSION}

Pinrang district has a large human resources with more women than men. Women in this district need to be given skills in processing natural resources in their area. Local governments must also support women's empowerment. Action that has been done by the local government is to provide opportunities for women in developing entrepreneurship business. This entrepreneurship can develop the excellent potential of the region especially in traditional food or cake.

Successful entrepreneurship will improve the family economy. Improving the family economy will build a family welfare that ultimately is a form of soft power in the government's strategic support in preventing the occurrence of terrorism in its territory. The development of regional potential is one of the new approaches to support women empowerment. There are several entrepreneurial efforts that have been built by the Pinrang community, such as pancake business. This pancake cake is one of Pinrang people's traditional food that is usually served at religious and traditional events. Traditional pastry or traditional food has its own meaning, such as food can give expression about relationship of interpersonal, traditional food expressing relationship between one person with another, and traditional food can show one's social status. This condition provides an explanation that traditional food has a big meaning. Therefore, local governments have an obligation in maintaining the preservation of traditional food. One of the efforts in maintaining its sustainability is by empowering women. This study is limited to entrepreneurship for traditional cakes only. For the future research, entrepreneurship for larger businesses is also needed such as traditional food that has a larger capital.

\section{ACKNOWLEDGMENT}

We are grateful to Hasanuddin University that has provided funds in support of this research activity. Thanks also for the community and government officials of Pinrang Regency in providing sufficient data for this research.

\section{REFERENCES}

[1] R. Cooper, "Hard Power, Soft Power and The Goals of Diplomacy." In Davied Held/Mathias Koening-Archibugi (eds). American Power in the $21^{s t}$ Century. Cambridge: Polity Press. 2004. Pp.167-180

[2] B. Dominic, "'Womens's Education a Tool of Social Transformation'A Historical Study Based on Kerala Society." International Journal of Scientific \& Engineering Research. Volume 2. Issue 10. 2011.

[3] N.C. Fink, R. Barakat, and L. Shetret. The Roles of Women in Terrorism, Conflict, and Violent Extremism: Lesson for the United Nations and International Actors. USA: Center on Global Counterterrorism Cooperation. 2013.

[4] S. Haryani, and B. Motwani. "Discriminant Model for Online Viral Marketing Influencing Consumers Behavioural Intention." Pacific Science Review B: Humanities and Social Sciences. 1. 2015. Pp.49-56.

[5] G. Ma, "Food, Eating Behavior, and Culture in Chinese Society." Journal of Ethnic Foods. 2015. Pp.195-199.

[6] J.S. Nye, Foreign Policy. No.80, Twentieth Anniversary Autumn. Washingtonpost. Newsweek Interactive,LLC. 1990. Pp.153-171.

[7] J.S. Nye, Understanding International Conflicts: An Introduction to Theory and History ( $7^{\text {th }}$ Edition).2009. New York: Pearson

[8] K. Robinson, and S. Bessel. Women in Indonesia: Gender, Equity and Development. Singapore: Institute of Southeast Asian Studies. 2002.

[9] A.B. Starman, "The Case Study as a Type of Qualitative Research." Journal of Contemporary Educational Studies. 2013. Pp.28-43.

[10] W. Suryana, Menlu Retno Tegaskan Peran Penting Wanita Melawan Terorisme.http://www.republika.co.id/berita/dunia-islam/islamnusantara/16/11/04/og3j22396-menlu-retno-tegaskan-peran-pentingwanita-melawan-terorisme. Khazanah, Repbulika. Jumat, 4 November 2016. Retrieved September $2^{\text {nd }}, 2017$.

[11] J.C. Maxwell, A Treatise on Electricity and Magnetism, 3rd ed., vol. 2. Oxford: Clarendon, 1892, pp.68-73. 